\title{
An Essay on Economic Values of Akhism Agim Mamuti*
}

\begin{abstract}
The purpose of this paper is to provide an overview of the Akhism with the special reference to its economic aspects. Akhism was effectively functioning from the end of the Seljuk to the late Ottoman period. Akhism, with some modifications, played an important role in the establishment of an effective economic and social structure, by bringing together socio-economic factors such as ethics, production and trade. Then, Akhism succeeded in creating an effective and reliable network of relationships between citizen and state, rich and poor, producer and consumer and labor and capital. Akhism also established the working and corporate principles based on morality and social justice. Akhiis is an Arabic word which is defined as a "brother" (Akca, 2004, 356). In another source it is stated that this word is derived from $A k l$ which means in Turkish language bravery, heroism and generosity (Bayram, 1991, 131). The brotherhood culture prevalent in Akhism has also been effective in the formation of social order and spreading of tolerance and understanding in the society. Akhism institution and tradition has been influential in economical, financial, social and cultural aspects of life. In the past and even today it has been dominant in organizing craftsmen and artists and in integrating them in a definite system and order.
\end{abstract}

Keywords: Akhism, Economic Thought, Ottoman Empire, Balkans and Artisans

\footnotetext{
* Agim Mamuti, Assistant Professor, Faculty of Business and Administration (FBA), Sarajevo, Bosnia and Herzegovina, E-mail: amamuti@ius.edu.ba
} 
It is questionable to explain the causes of economic development and underdevelopment of nations by using only the material elements because production and consumption are also human activities. Thus, human behavior is main subject of fundamental economic activities of production and consumption. The factors that certainly affect human behavior include the geographical conditions, social environment, climate, population, politics, culture and religion. Just like each of these may have a separate effect, a very different effect may also occur from their mutual interaction, and their prediction is not easy task. But religion is the most effective one among them and also it has determining features.

The social ethics, which is formed in the axis of religion, depends on each element and constitutes the main parameter of the behaviors of a particular society. In this regard, Ibn Khaldun, by comparing the economic position of different communities, claimed that social progress should not be connected only to the personal property. He emphasized also environmental and cultural factors that must be taken into consideration (Kozak, 1984; 152). Similarly, Weber also accepted that the social environment, the geographical environment, history, culture and religion also affect a society's morality and behavior (Weber, 1993; 228). Throughout the history the Akhi organization depended on a religious and customary education system with the application of a strict discipline. It is known that $A k h i$ organization made a great contribution to the Ottoman-Turkish society.

Akhism organization also included an education system that is continuous with strict rules and a system of discipline. In this system, Akhis begin with a training process by following three stages and ninegrades. "Sharia doors," expressed as a first stage, include training of disciples in the professional knowledge, the Qur'an, reading and writing, Turkish language, mathematics and in the Futuwwa as nature of the organization's constitution. "The sect door" as the second stage, involves the highest level of professional knowledge. This stage also includes teaching, knowledge of mysticism, music, Arabic, Persian and separate military training. At the third stage, as named "trick at the door", rank of the Sheikh is attained, who believes in God, soulnessness, deep moral 
training and service to the community. The main purpose, as described "in order, to truth" in the philosophy of Akhism, is to be close to God. Similarly the education system attempts to realize this goal, because, people will be able to reach "a perfect human being" as a result of such an education system.

Just like in Futuwwa, which can be expressed as Ahism's constitution, Akhism depends on nine grades system. Degrees that are relevant to the Akhism are as follows: Valiant, Assistant, Apprentice, Foreman (Journeyman), Master, Akhi, Caliph, (Khalifa), Sheikh, Sheikhulsheikh (Well-ul Meşayıh). Valiant and Assistant at the first two phases make the preparation of the introduction to Akhism organization. The third stage, "apprenticeship", represents the phase of admission to the organization. Other phases that consist of Journeyman, Master, Akhi, Khalifa, Sheikh and Well-ul MeĢayıh degrees, reflect the ratings mainly of professional administrative degrees. The transition from one phase to another averaged 1000 days, which requires a period of nearly three years. But it is possible to shorten and prolong this period according to the individual skills (Öztürk, 1993; 4).

During the late Medieval and Early Modern periods virtually every state in the Old World had to address a common range of economic problems. The most basic of these problems were related directly to the maintenance of the states. The provisioning of the capital city, the armed forces, and to a lesser extent other urban areas, taxation, support and regulation of long-distance trade, and maintaining a steady supply of money were amongst the leading concerns of the economic policy.

Even though the capacity of states to deal with these economic problems was initially quite limited, important changes took place during these centuries in the capacities, institutional equipment and even the nature of governments. According to Charles (1975) these changes were coupled with a corresponding transformation of the scope and effectiveness of government intervention in the economic affairs. It was precisely this effort to build the organizations and institutions necessary for the detection of these policy goals that led to appearance of more powerful state apparatuses in certain parts of Europe and Asia. While designing the economic system, the main aim of capitalism is the 
maximization of the profit, whereas, the aim of the economic approach of Akhism system has been to maximize the social benefits in contrast to the maximization of the profit (gimĢek, 2002; 133).

Akhism organization that aims at the societal benefit is a civil organization that is often founded by tradesmen and craftsmen. Akhism as an organization directly affects the economical life of the society. The functions of the Akhism organization in comparison to the equivalent organizations today are quite similar. It is possible to arrange them in order as follows: commerce of industry and chambers aims at solving the industrial and business problems; unions of labor and employees regulate labor and employee relations; competition authority prevents the monopoly; bodies of goods and service standards protect consumers by controls of the quality of goods and services. Therefore, Akhism organization has carried out similar mission and had similar structure as many modern organizations. Actually, Akhism principles and business system made significant contribution towards socio-economic flourishing of the Ottoman Empire.

Remarkably different results were reached about the relationship between economic growth and social capital by many empirical studies in the recent years. In this regard, Putnam (Putnam, 1995) found social capital to be effective, on the fall of the crime rates, governments to work more efficiently and to reduce corruption. Fukuyama (2000) identified that the cost of the transactions decreased due to the operations related to trust. Coleman (1998) identified that success increased in education. Wilkinson (1996) identified correction of the income distribution and Whitley (2000) identified acceleration of the economic growth that has been established by the positive effects of the social capital.

Apparently, an internal social conflict in less developed countries is greater in comparison to developed countries that managed to secure social peace and harmony. Actually, the economic and political success is closely related to the establishment of the social peace and harmony. It is necessary to analyze the economic, social and cultural factors, which create social capital that is one of the conditions for economic development. In this regard, moral structure, accumulation of social 
capital and developed level of interpersonal relations among the people and institutions was clearly envisioned by Akhism organization.

Akhism encourages its followers within organizational unit to emphasize the social peace and to work towards the establishment of trustworthy environment in the society. In this regard, Akhism teaches its followers moral values that are inevitable for building social peace and trust. Akhism values and social norms include: integrity, generosity, hospitality, tolerance, altruism, respect for people, solidarity, justice, conscience, freedom, equality, humility, living for people, being the devout, having sense of shame, not lying, not drinking, not having adultery and having abstinence (Gürata, 1975; 81).

The solidarity, tolerance and love in a country depend on the respect of the social traditions, shared values, culture, norms and social moral rules. In the periods during which Akhism was taking much more active role in Anatolia the right to a fair distribution of income was achieved and thus this laid the foundations of national unity. This peace and prosperity experienced in Anatolia also found an echo in the West (Demir, 2009). Therefore, the social capital concept that is the subject of current economic literature left a mark hundreds of years ago in Ottoman Turkish society, with the Akhi organization (Teaschner, 1953; 5).

In today's world, production of harmful products and services for artificial needs are often created by commercialists with the aim to maximize only profit, which are unhealthy and harmful for the individual and the society. Excessive emphasis on commercialism caused an environmental crisis and many economic and social problems that threatened the health of the individuals and the society. In contrast, while Akhism organization encourages to work and produce at every opportunity, issues of what is produced, how and how much is produced has been subject of the continuous control. Production has been evaluated as a function of necessary and lawful requirements according to the Akhism teachings. Therefore production and trade of goods and services that are non lawful and not necessary are often prohibited. In this context, aim of production in the organization of Akhism is not to make excessive profits but to meet the essential needs of the society, to produce high quality and aesthetic products (gimĢek, 2002;134). In this regard, an 
economic activity in the Akhism organization is based on the moral values. Production and trade of goods and services, which were produced illegally, in non-moral ways, and that may be harmful to human, were prohibited.

The Akhism organization left a mark in the Ottoman-Turkish community due to its teaching of arts at the workbench and manners in the lodges to its members from the Anatolian Seljuk State until in the $18^{\text {th }}$ century. The increasing of non-Muslim subjects that lived in the Ottoman Empire created the necessity of collaboration among people in various religions. As a result, "Lonca System" and later "Gedik System" were established. That was in the nature of monopolies and without discrimination of religion difference. It was carrying a continuation character of the Akhism organization. The Turkish word Gedik means a monopoly and a privilege. The people who were holders of Gedik had guarantee that others cannot do their job, and also had the privilege to use the rights in writing the charter or bill given by the state. This style of trade and artistry career continued until 1860 (Pamuk, 1990; 58).

Akhism organization, which has been functioning successfully for around 630 years, from the last periods of Seljuk Empire until the last years of the Ottoman Empire, has been affective to the Anatolian Turkish society in the areas of art, trade and economics. Akhism organization also showed the effects at every stage of life of the community. Akhism organization has made very important contributions in economics, social and military aspects of the Ottoman Empire. There are also claims that Akhism took an active role across the three continents of the Ottoman Empire. Besides, this system has brought the solution to the most important problems of today's world such as inequitable income distribution, sale of the fraudulent goods, corruption, bribery and poverty issues, with a higher moral level and comprehensive education system.

Akhism organization was a professional non-governmental organization that had an aim to educate a society in advanced moral principles. Akhism is a strong corporate structure, based on masterapprentice relationship and comprehensive education system, unlimited obedience-based on the elders. Also it is an organization that had the purpose to train conscious people who are qualified in responsible way 
towards both the community and the state. Akhism as the system aims to primarily educate and to produce a high moral person rather than extremely rich person. Such a person should achieve the success in the economic, political and military areas. Finally, by using educational tools it can construct sincere and trustworthy social relations. 


\section{References}

Anadol, Cemal 1991. "Akhism Culture and Fütüvvetnameler in the Turkish-Islamic Civilization," Ministry of Culture Publications, Ankara.

Barro, Robert J. 1992. ed. Jakson Hole, "Human Capital and Economic Growth”, Policies For Long-Run Economic Growth, Federal Reserve Bank of Kansas City

Cahen, Claude. 1986. “About First ahi”, (Trnsl., M. ÖZTÜRK), Belleten, p.197, Agust. 1986.

Coleman, J. 1998. "Social Capital in the Creation of Human Capital", American Journal of Sociology, 94 Supplement PP. 95-120, University of Chicago.

Çagatay, Neset. 1974. "The Akhism as an Turkish Institution”, Ankara. Çagatay, Neset. 1989. "The Akhism as an Turkish Institution”, Ankara.

Çagatay, Neset. 1990. "What is Akhism?, Folk Culture Research Department of the Ministry of Culture Publications, No:137, Ankara.

Demgr, Galip. 1993. "Akhism in the Past and Present and Consumer Protection Relation”, Journal of Standard.

Dogan, Mehmet. 1973. "Ottoman Empire, Peak of the Turk Islam Composition", Journal of Movement, Number. 89.

Ekinci, Yusuf. 1989. "Ahi and Vocational Education", Ministry of Education publications", No: 62, Scientific and Cultural works Series, No.132.

Ekinci, Yusuf. 1991. "Ahilik ve Esnaf Ahlakı", Standart Dergisi, Number, 350.

Fukuyama, F. 2000. "Trust, Social Virtues and the Creation of Prosperity",

Gurata, M. 1975. "Forgotten traditions and Guilds", Ankara.

Karagul, Mehmet. (2002), "The Role of Human Capital in the Economic Development, and Size of Turkey", Afyon Kocatepe University Publications No: 37, Afyon.

Kats, Lawrence F. 1992. ed. Jakson Hole, "Commentary: Human Capital and Economic Growth", Policies For Long-Run Economic Growth, Federal Reserve Bank of Kansas City. 
Kazanci, Ziya. 1987. "Ihtisap Organization in the Ottomans", Victor Printing, Istanbul.

Kozak, E. 1984. "According to Ibn Khaldun the Society and the Economics", Spring Publications, Istanbul.

Naganci, Gükrü. (2002), “Ottoman Economic Mentality”, Okumus Man Publishing, Istanbul.

Özturk, Ibrahim. 1993. “Akhism”, Journal of Akhism Road, Number, 84.

OECD. 2001.The Well-being of Nations, The Role of Human and Social Capital, pp. 41, 43 ,45.

Putnam, R. 1995. Bowling Alone - The Collapse and Revival of American Community, New York.

Sevgenc, Necdet. 1978. "Socio-Economic Structure in the Ottoman Empire 1", Publisher Kutsun, Istanbul.

Taeschner, Franz. 1954. "Organization of Generosity the Islamic Medieval Age", Journal of Faculty Economics, Vol. XV, No: IIV.

Tatar, Taner and DÖNMEZ, Mehmet. 2008. "Ahi Organization the Framework of Relationship between Mindset and the Economic", Research in the Eastern Anatolia Region.

Ürkdogan, Orhan. 1988. Sociology of Social Movements, Ankara.

Ülgener, S. "Mentality and Religion: Islamic Mysticism and the Economics Ethics in the Thawing Cycle", Der Publication, Istanbul.

Ünver, A.S. 1969. "European Impressions, Three Centuries Ago A Officially Registered", Approval Publications, Ankara.

Weber, Max. 1993. "Sociology Articles"

Whiteley, P. F. 2000. "Economic Growth and Social Capital", Political Studies, Vol. 48. 